\title{
MALAYSIAN DEMOCRATIC DILEMMAS IN
}

\section{THE ERA OF NAJIB RAZAK}

\author{
Saiyid Radzuwan Syed Sopi
}

Ahmad Fauzi Abdul Hamid

\begin{abstract}
The objective of this research is to see how Prime Minister Najib Razak has manipulated the concept of democracy in fulfilling his needs to remain in power. The focus of this study is to find out why Najib is willing to exploit state institutions such as the bureaucracy - police departments, anti-corruption agency, the Attorney-General's office, and cooperate with cabinet members to ensure that he perpetually clings to power. In principle, most third-world elites are quite happy to dismantle existing institutions (parliament, elections) in the interests of continued rule. Besides that, those who are already in power are often view institutions more as obstacles and less as facilitators of effective rule. This research finds those who support and protect Najib realize that some actions of their boss are illegal, but they pretend to support him in order to fulfill their selfish desires. A leader will preserve his power when most of his supporters have become blinded by the trappings of power. They know Najib's faults but still support him. Whatever wrongs Najib has done, they still support (him).
\end{abstract}

Key words : democracy, bureaucrats, dismantle, power, Malaysia, Najib Razak

\section{Introduction}

According to Huntington (1991 : 6), democracy is defined in terms of sources of authority for government, purposes served by government and procedures for constituting government. In this definition, a government can apply the terms of democracy as a power to manage, control the country and to manipulate the system for personal interest. Austin (1975: 18) mentions that power is at the heart of politics, it is always the power that determines relations to someone (or some groups) over someone else (or some other groups). The central dialogue in a political life is between those who see the inevitable relationship of unequals as desirable, just, and legitimate, and those who see it as undesirable and unjust. The former works, in their political activity, to extend and solidify the relations of power; the latter work to restrict, ameliorate, dissolve or abolish them.

Malaysia's sixth Prime Minister Najib Razak had been accused of abusing his position as a prime minister (Nawar Firdaws 2016). ${ }^{1}$ Why is someone willing to act in violation of the laws of the country merely to remain in power? The reality is that power is the major concern of political elites and with power, they can do anything to meet their personal interest. Once they are in power, they will try to maintain, sustain and ensure that the power belongs to them forever. Besides that, they will restrict or eliminate any individual who tries to usurp the power from their hands. Furthermore, without feeling 
guilty, they are proud to be able to violate democracy (Magill 1996 : 1145-1147, Huntington 1991 : 111, Machiavelli 1950).

Their actions are consistent with the views of Ball (1988 : 26-27) that political power is, then, the capacity to affect another's behaviour by the threat of some form of sanction. The greater the sanction, or the more numerous the sanctions, the greater will be the political power. The sanctions may be negative or positive. Thus a political leader may acquire compliance with his wishes by promising those who support him wealth or honours, or he may threaten to deny such rewards to those who oppose him. Most exercises of political power include both. The penalties for opposing the holder of political power may be severe, such as imprisonment or even death. These latter penalties are usually reserved for the state, and those who control the state often wield the strongest political power. However, it is the fear of these coercive penalties that ensures the obedience, not the coercion itself; indeed a too frequent use of these penalties may be an indication of the weakening of that political power.

Today Najib remains in power as Malaysia's prime minister, in full realization that power would not held forever. Therefore, he and the UMNO's members have to "reinvent" the party and discover a fresh approach so as to maintain its hegemonic position. Political scientists such as Migdal (2001 : 16-17) and Alagappa (1995a : 26) argue that for a regime/government seeking to cement its authority, one potential strategy is to draw upon the universal appeal of the nation-state as the basis for political community. Promoting an image of the nation-state as a single territorially and socially bounded entity and then associating with the image is a potentially powerful means for a regime/government to legitimate its authority.

However, this is often easier said than done. The practices of regime/government actors tend to be quite diverse and while some may indeed reinforce and validate a popular image, other practices may mar its sanctity or disrupt the ostensible unity of the population, thereby threatening the coherence implied by a common image (Migdal 2004). So while it may be correct to regard the nation-state as invisible, as something that must be "symbolized before it can be loved," the units of discourse and feeling around which "emotions of loyalty and assurance can cluster" depend on the social practices of the regime/government vis-à-vis such symbolization (Walzer 1967 : 191-204).

In justifying a practice, an actor is "literally [attempting] to connect one's action with standards of justice or ....standards of appropriate and acceptable behavior" (Finnemore 2003 : 15). The key, therefore, to understanding how particular articulation of legitimate political authority are possible lies in carefully studying the ways in which regime/government practices converge/diverge from the officially projected image of the associated nation-state. That is, the manner in which political actors justify the practices of the regime/government with reference to an image of the nation-state and the degree to which such justifications are accepted or rejected by society reveals the underlying normative context from which legitimate political authority can be derived (O'Shannassy 2013 : 431). 
A detailed analysis of Prime Minister Najib Razak's concept of 1Malaysia since its inception in 2009 is one means by which such processes can be explored. On the one hand, 1Malaysia could be interpreted simply as an instrumental strategy. UMNO, in an attempt to appeal to a more progressive populace and recoup its electoral losses, re-casts itself as the party for all Malaysians and not just that of the majority ethnic group. But, 1Malaysia betrays much in political rhetoric, unearthing Najib's political strategy to enhance his reputation as a leader. This type of strategy was not used only by Najib, but also by many prime ministers or presidents, displayed particularly in his/her first speech as a leader.

In this article, we draw upon Najib's political record in arguing that he has manipulated the state institutions to meet his personal interest. In the first section, we discuss how Mahathir pressured Abdullah Badawi to step down and the strategies used by Mahathir to meet his agenda. Mahathir believed that Najib was the best candidate to govern the country because he was a protégé of Mahathir. As former Deputy Prime Minister Musa Hitam argued, Prime Minister Najib's determination to cling onto power despite being criticized from all sides shows he is a very good student of his now most vocal critic, Mahathir Mohamed (Yahoo News 2015). ${ }^{2}$

The second part investigates the destruction that Najib has done to the country. Najib has faced sustained pressure to resign since last year over his links to 1 Malaysia Development Berhad (1MDB) a heavily indebted state invested fund that he established, as well as payments into his private accounts totaling nearly USD 681 million. But Najib denied any wrongdoing and maintained that he has not used the funds for personal gain, with aides saying the payments were a political donation from Saudi royal family (Adam Taylor washingtonpost.com 2016) ${ }^{3}$ Thus, Mahathir felt disappointed with Najib's character and promised to do anything to bring him down.

\section{Najib Razak before becoming prime minister}

Najib was seen as a savior for United Malays National Organization (UMNO) when the party failed to gain a two-thirds parliamentary majority in the 2008 general election, led by Abdullah Badawi. Many UMNO members hoped that Najib can make a difference and improve the party's weaknesses. Besides that, to win back the people's support, Najib introduce a flurry of transformative policies and projected a more inclusive image of government. The opposition, on the other hand, continued to push for more democratic space, end of the corruption and cronyism, respect for human rights and more inclusive economic policies. This set the scene for defining the next elections that saw the battle between the ruling party transformation agenda versus the opposition's promise to change.

The resignation of Abdullah Badawi was engineered by former Prime Minister Mahathir Mohamed, he believing that Abdullah Badawi had failed to perform his responsibility as head of the government. But, that was not the actual reason Mahathir wanted to topple Abdullah Badawi. Abdullah Badawi had acquiesced to Malaysian Federal Court's acquittal of Anwar Ibrahim hence releasing him from prison. Besides 
that, early in his tenure, Abdullah Badawi had cancelled several large infrastructure projects, most famously an electrified double railway that was to have run the length of Peninsular Malaysia's west coast (Case 2016 :16). ${ }^{4}$

He ordered a review of the Bakun hydroelectric project in Sarawak and he scaled back plans for a new customs facility and elevated bridge link between Malaysia's southern state of Johor and Singapore. More generally, Abdullah Badawi advised also that any additional contracts would be awarded not through opaque and personalist dealings, but instead through open tender bidding (The Economist 2004 : 25). What had been done by Abdullah Badawi disappointed Mahathir. Hence, Mahathir believed that by replacing Abdullah Badawi, the abandoned project can be continued by a new prime minister.

Mahathir could give thousands of reasons and ideas to fulfill his personal interest. This scenario gives with the understanding of politics as an activity concerned with conflict, compromise, decision-making, power and authority (Ball 1988 : 32). As a veteran politician, Mahathir realized that ideas that encourage the stability of the existing system can be manipulated by political leaders to increase their political power; e.g. the claim that the state is in danger from certain hostile elements, and the government needs extra power to tackle them. Therefore, with enduring influence, Mahathir could steer the Malaysia political landscape according to his interests.

Under Najib's leadership, UMNO hoped that Mahathir's clout would force Abdullah Badawi to step down as a prime minister. In UMNO members' minds, the image of Mahathir will mould negative thinking about Abdullah Badawi, as if Abdullah Badawi was not a good leader. Basically, people not in power will do their best to wrest political power from the incumbent. But, when they are in power, are they really outstanding as a leader? This situation of leadership deficit has parallels with Japanese politics where political and policy issues are the main instruments used by rivals to unseat the incumbent (Mulgan 2000 : 192). Those offering what look like decisive plans for change are often merely political opportunists seeking to undermine incumbent rivals. Once in power, they would behave no differently from their predecessors. Inoguchi (1997) has therefore labeled Japanese politics as a "karaoke democracy", where everybody, no matter how good there are, get a turn to become a prime minister.

Normally, karaoke was a form of entertainment designed to provide an opportunity for anyone interested to sing, entertain or have fun. There are no conditions imposed on those who like to entertain through karaoke and anyone is given the opportunity to sing. Furthermore, participants are given special access to present their song. Such a parable can apply to LDP politicians because most of them think that they have the ability and are qualified to be leaders of the country, despite their questionable capacity (Saiyid Radzuwan 2014 : 175). Hence, the parallel drawn by Japanese political analysts like Inoguchi in arguing that LDP's politicians treat politics in a similar way to the world of entertainment as in karaoke. 
In politics, phenomena that are unpredictable, inevitable and previously impossible can become possible. Politics is the art of possible and each politician has to be wary about the game of the politics. For instance, Abdullah Badawi became a prime minister not because of his talent, but Mahathir had to fulfill the position vacated by Anwar Ibrahim with somebody who can protect his personal interest. Many observers predicted that Abdullah Badawi, ascending to the prime ministership of Malaysia in October 2003, would not last long a national leader. From the outset of his premiership, speculation had mounted over his impending replacement by UMNO's most senior Vice President, Najib Razak (Case 2016 : 5).

Cabinet members, high ranking bureaucrats and UMNO's top leaders knew that what Mahathir was being undemocratic, yet they did nothing to prevent Mahathir from continuing his efforts to topple Abdullah Badawi. The question is whether the elite members of the party, the government and influential people agree with Mahathir or did they play safe in order to ensure their positions? The answer was that all the interest groups which were involved directly or indirectly in political decision making believed that any decision that was done by the prime minister was right and they should not be questioned even if the action was wrong. Thus, this is the weakness of the Malaysian society and they need to reform their thinking to be become an advanced country.

\section{Najib after becoming prime minister}

It is clear that leaders can extensively control and manipulate their party and it is equally clear that leaders generally try to maintain the consensus of their following. A well known theory of organizational power captures the "sense" of intra-organizational relations far better than theories which can be found in party literature : the theory of power as an exchange relation (Blau 1964). In the words of two of its representative supporters as Crozier \& Friedberg (1977 : 59) argue;

Power can once again be defined as a relation of exchange and therefore reciprocal, but in the sense that the exchange is more favorable for one of the parts involved. It is a relation of force, in the one is advantaged over the other, but when the one can, however, never totally be defenseless with respect to the other.

Power is therefore not only relational and asymmetrical, but also reciprocal. It manifests itself in an "unbalanced negotiation" in a relation of unequal exchange, in which one actor receives more than the other. Power is, thus, never absolute : its limits are implicit in the very nature of the interaction. One can exercise power over others only by satisfying their needs and expectations; one thereby paradoxically submits oneself to their power. In other words, the power relation between a leader and his followers must be conceived as a relation of unequal exchange in which the leader gets more than the followers, but must nonetheless give something in return (Panebianco 1988 : 22).

Najib realizes that to become a good leader, he must present better credentials and display better abilities than Abdullah Badawi. In addition, many commentators, analysts and even opposition politicians anticipated that Najib would be a much tougher political 
opponent than his predecessor Abdullah Badawi when he took over the premiership in April 2009 (Yeoh 2009). Najib's "unpredictably strategic" moves in his hundred days in office have continued to be his modus operandi in 2010, leaving not much room for the opposition to undermine his political standing among the electorate. A review of his major accomplishments and challenges during the year will demonstrate Najib's political agility and skill in successfully navigating most of the potential pitfalls and maintaining his focus on the key deliverables that would increase his personal popularity and political standing (Ming $2011: 132$ ).

Bernand Crick (1964) argues that politics means discussion and discussion entails opposition.

Politics is a process of discussion .... For discussion to be genuine and fruitful when something is maintained, the opposite or some contrary case must be considered or - better - maintained by someone who believes it. The hall-mark of the free government everywhere...is whether public criticism is allowed in a manner conceivably effective - in other words, whether opposition is tolerated. Politics needs men who will act freely, but men cannot act freely without politics. Politics is a way of ruling divided societies without undue violence - and most societies are divided, though some think that is the very trouble. We can do much worse than honour 'mere politics' so we must examine very carefully the claims of these who would do better.

Political parties are only one part of a system of politics and government. Nevertheless, in systems based on free and fair elections they are a crucially important apart, because they are the channels by which public opinion, expressed through the ballot box, is brought to bear on the machinery of government. Following Crick, therefore, we should expect politics to be practiced in the shape of regular debate between a party or parties that occupy the seat of government and a party or parties that constitute the 'opposition'. Nobody would argue that such debate is merely disinterested discussion, like a series of academic seminars. In practice, the parties and their leader are trying to score points off each other while parties out of power seek to place themselves in a favourable light so as to win the next election, parties in power seek to defend their record and impress the electorate with their current and past performance. Politics includes the search for political advantage, just as much as it includes debates over policy choices (Stockwin 2006 : 116).

Mahathir and other UMNO members at first believed that Najib could make a good prime minister. In Mahathir's opinion, Najib would comply with the rules and instructions that both of them had agreed before. Besides that, Najib was seen as having good leadership capabilities just like his father, Tun Abdul Razak. But, such a portrayal of Najib was pre-mature. Najib has damaged several institutional structures and practices that characterize Malaysia politics and governance. We will discuss here three of his follies. First, the government implemented a 6\% Good and Services Tax (GST) on April 1,2015 , placing great strains on household expenditure. 
For Najib and his cabinet members, GST was one of the sources for government to obtain funds from people. With the money, government could improve the public infrastructure, public transport, enhanced educational standards and anything related to the people. But, a major question surfaces : is GST seen as a means to improve services to the public or to save government from bankruptcy? Based on the Auditor-General's yearly report, almost all of the ministries showed a negative performance especially in financial management. ${ }^{5}$ Anwar Ibrahim argued, most of the ministries practiced cronyism and were riddle with financial management, causing leakage and resulting in losses of millions of ringgit in the ministry each year. ${ }^{6}$ Thus, Najib urgently needed extra and financial resources to save the country's economy and the best idea to resolved this problem was to implement the GST.

Ahmad Maslan was appointed as the deputy minister to ensure that the information and the process of GST proceeded smoothly. He gave many reasons why GST was suitable to be implemented in Malaysia although the opposition party argued otherwise. Besides that, Ahmad Maslan had used government facilities such radio, television, media and produced a short video clip by using drama actors to promote GST. ${ }^{7}$ In addition, Ahmad Maslan acknowledged the criticism he received for defending Putrajaya's implementation of the GST, but said he still remained supportive of the tax system because of his personal relationship with Najib.

Basically, there are more than 160 countries around the world that have implemented GST and if we look into the politics scenario, the ruling party is not likely to survive in government as soon as they implement the tax. For instance, from April 1, 1989, the Japanese began to pay a 3 percent consumer tax for all items across the board, even for daily food, child bearing and funeral expenses. ${ }^{8}$ Due to the implementation of the tax, Japan's dominant party - Liberal Democratic Party (LDP) - lost the general election of 1993. Therefore, UMNO must do something to prevent their party from losing power. They must learn their lessons from LDP's experience (Muhamad Takiyuddin and Ahmad Fauzi 2014).

Malaysia is not the first country in the world which implements GST. Why did bureaucrats and cabinet members from the ruling party do nothing to prevent the government from introducing GST? The answer in the fact that many of them felt guilty if they said no to the government's policy because many of them got promoted based not on their qualifications, but on their intimate relations with the party in power. ${ }^{9}$ Besides that, the opposition party took the initiative to have a roadshow and give a clear information to the people, society and public community about the problems and burdens if the government vigorously implemented GST.

Second, Najib's government gradually reduced the subsidies that may give a negative impact to peoples, increasing the cost of living. Subsidies on goods such as fuel, sugar, and cooking oil had cost the government around RM42.4 billion in 2012 - a huge amount that is equivalent to Malaysia's budget deficit. In early September 2014, the government announced a 20 cents rise for RON95 petrol and diesel fuel, the first increase since 2010. A few days later, it announced an increase of 15 cents for RON97 petrol. 
Amid concerns of potential inflation, Najib defended the government's decision stressing that reducing state subsidy was necessary given the challenging external environment. Not doing so would mean a growing fiscal deficit and greater medium term risks.

Furthermore, where Najib is perhaps most vulnerable is in the area of minimizing the fallout from expected price increase. The petrol hikes which explained part of the voter backlash against Abdullah Badawi in the 2008 elections also took place in 2010, but were introduced more gradually and by smaller amounts, thereby shielding Najib's administration from the same degree of voter backlash. The price per liter for RON95 was increased from RM1.80 to RM 1.85 in July 2010 and then increased to RM1.90 in December 2010. The price of RON97, sugar, diesel and cooking gas were also increased in stages in 2010 as part of a larger subsidy rationalization programme meant to slowly decrease government expenditure and slowly reduce the overall budget deficit.

Increase in worldwide commodity and food prices also add to domestic inflationary pressure. Even though the inflation rate will not likely to rise beyond 5 per cent, it is the extent to which the average consumer is "hit" in the pocket, so to speak, which will have an effect, politically, on Najib's administration. The official inflation rate does not adequately capture the much higher increase in prices, especially of the nonprice controlled items within the basket on goods used to calculate the official inflation rate, in the urban areas. The popular satellite subscription services, ASTRO, is not listed in the basket of goods, but it has well over a million households which subscribe to its services and these customers will see an increase of 6 per cent in their ASTRO bills in the new year as a result of the service tax being extended to cover satellite television (Ming $2011: 141)$.

Reducing or gradually abolishing the subsidies will give an adverse impact on people, especially the low and medium income groups. Malaysia has high household debt and the biggest portion of the Malaysian household debt goes to paying off housing loans followed by passenger car loans, personal use, securities purchase and credit card. Malaysian household borrowings hit 86.3 per cent of Gross Domestic Product (GDP) in 2013 when it has been just 60.4 per cent in 2007, surpassing even the United State's 80.6 per cent registered in the first three months of 2014. A major contributor to local household debt in Malaysia is the people's affinity to cars, which are among the world's highest priced. This was followed by the rise of home prices and thus reduces the purchasing power of consumers. In addition, it became worst when the government implemented the GST which would surely place further strains on household expenditure. McKinsey Global Institute (MGI 2015) in its report warned that,

Untenable household debt in some of the world's largest economies, such as the U.S. had been at the core of the 2008 financial crisis. These figures suggest potential risks but do not signal imminent crisis. Nonetheless, these countries should, at the minimum be monitoring the situation very carefully.

Besides that, the increase of toll rates will have great impact on the daily lives of Malaysians. Starting October 15, 2015, 18 highway concessionaires will impose new 
rates for toll lanes. ${ }^{10}$ Almost all of them involved routes in the Klang Valley, but the KLKarak and the Butterworth Outer Ring in Penang were also involved. It saw price increases of $17 \%$ to $80 \%$ between 20 cents and RM1. The government keeps giving the excuse that the toll increase had to be implemented to prevent the government from paying compensation to concessionaires. This cannot be accepted by common sense because the government has the authority to prevent any increase in toll rates.

Finally, Najib has demolished the Malaysia institutions by using his power to arrest and summon anybody who criticized him. Worse, people suspected of knowing too much about Najib's misdemeanour were allegedly made to disappear, thus eliminating the evidence of investigation. (Ida Lim 2015). ${ }^{11}$ As a nation that practices democracy, each individual was bound to respect the law and constitution. Najib had committed the greatest mistake in his career as a politician when he abused his position as a prime minister. He had intervened in national institutions such as the police, bureaucracy and the anti-corruption agency. Najib was accused of mega financial scandals and to make himself clean, he developed conspiratorial linkages with the police, Attorney-General, cabinet members and anybody who has vested interests with him. Mahathir argues that UMNO is no more a political party but it is Najib's party when almost all of the cabinet members are protecting Najib rather than the country. ${ }^{12}$

Huntington (1971) argued the most important political distinction among countries concerns not their form of government but their degree of government, and asserts that the primary problem of politics is the lag in the development of political institutions behind social and economic change. With the slogan of "cash is king", Najib believed that money was the power to make somebody follow his orders and with the money, he could build better relations among his followers (malaysiakini 2015). ${ }^{13}$ In reality, the Malaysian Prime Minister is very powerful and he has the authority to change the impossible to become possible. Indeed, political order in developing countries is probably jeopardized more by those in positions of authority than by social mobilization from below. James Scott notes,

In most of the third world we have what I would call "profligate" elites who are willing, even anxious, to undermine the survival value of political institutions in the interests of continued dominance. If so, then the problem of "threatened institutions" as Huntington sees them is not a problem of being swamped by "socially mobilized masses of unwashed" but of an artificial cloture of rigidity produced by incumbents. In fact, most third-world elites are quite happy to dismantle existing institutions (parliament, elections) in the interests of continued rule. $^{14}$

Furthermore, regime leaders are often hostile to institutions, particularly parties, and undermine them when they prove inconvenient. As Atul Kohli (1994 : 95) has remarked, "those who are already in power ....often view institutions more as obstacles and less as facilitators of effective rule". Such was the case with Marcos after he inaugurated martial law. His bid to concentrate power brought immediate benefits; it sequestered political gadflies and tied the ruling circle to him. When he abandoned the 
party, Marcos planted the seeds of elite defections and electoral defeats. His disdain for the party institutions at the inception of his dictatorship spawned the crisis that later toppled him (Brownlee 2008 : 104).

To assert his authority, Najib used his power to sack Muhyiddin Yasin as Deputy Prime Minister and UMNO Vice President, Mohd Shafie Apdal as a full minister in a cabinet reshuffle on July 28, 2015. Muhyiddin and Shafie were removed from the government for their criticism of Prime Minister Najib's handling of the state-owned 1MDB. Besides that, Mukhriz Mahathir was forced to resign from his position as a Kedah Chief Minister on February 3, 2016. According to a statement from the Prime Minister's Office, Najib reiterated that Mukhriz had to be removed as he had lost the support of the majority of state assemblymen, adding that UMNO and the government must be disciplined and work together as a team in order to effectively face the economic and security challenges (channel newsasia 2016). ${ }^{15}$

Najib had not only sacked his party member from government posts, but government servants who were involved directly in the investigations on the 1MDB scandal. ${ }^{16}$ Najib was trying to divide and rule the $1 \mathrm{MDB}$ investigation teams in order to prove that he was not involved in the mega financial scandal. In Indonesia almost two decades ago, Soeharto had used the divide and rule strategy to make sure he was in power for almost three decades. Soeharto was able to achieve this through various means. While he was able to control the military, he was unable to gain its full support. In response, he divided the military into groups, so that no group would be strong enough to challenge him. Another vital controlling device was the establishment of his own foundations (yayasan), controlled by him and his family, to ensure the flow of funds for political purposes (Suryadinata 1997a).

As a prime minister, Najib has the power to replace or sack his cabinet minister, bureaucrats in the police force or anti-corruption agency or government linked companies (GLC), Attorney-General and anybody who are involved directly in the investigation of $1 \mathrm{MDB}$ scandal with somebody who could support and protect him. The appointed persons must display their loyalty, commitment and responsibility to defend any allegations submitted against their boss. They realized that some actions of their boss are illegal, but they pretended to support him for selfish purposes. As Mahathir argued, a leader will preserve his power as a leader because most of the members who supported his boss have become dumb, deaf and blind. They know Najib's faults but still support him. Regardless of whatever wrong doings Najib has done, they still support him. ${ }^{17}$

\section{Conclusion}

Former British's politician, Lord Palmerston had mentioned that in politics, there are no permanent friends and no permanent enemies, only personal interests are everlasting (the hague trial 2016). ${ }^{18}$ Mahathir has fully supported Najib before he was elected as prime minister, but Mahathir changed his stand when Najib became prime minister. Why should Mahathir change the support given to Najib and cooperate with the opposition to topple Najib? Najib's father was also a former prime minister and there was a possibility that 
Najib was chosen by Mahathir to become a prime minister based on his father's reputation. But, the reality was Najib did not have leadership capabilities like his father.

In India in 1977, Indira Gandhi was selected to become prime minister because of her father's influence. Indira Gandhi did not show the aptitude of her father as a leader. As Candland (1997 : 24-25) mentioned, Mrs. Gandhi took personal control to Congress affairs, rather than allowing conflicts to be resolved at lower levels as Nehru had done. Decisions about the selections of chief minister and state "were made by Mrs. Gandhi herself in consultation with clique of personal advisors." Candland also added that Mrs. Gandhi dismissed and appointed Congress chief ministers and exercised, through the Office of the President, the government's prerogative to dismiss the opposition in state assemblies. The president, in practice, acts upon the instruction of the prime minister. But, Nehru used the president's rule sparingly.

To conclude, power is the main struggle for the politicians and they will do anything to preserve, maintain, sustain and make sure that power belonged to them for as long as possible. It was also same with the dominant party authoritarian regimes (Greene 2007) ${ }^{19}$ or party which have been in power for long periods of time by winning semicompetitive elections at regular intervals. They do not give up power easily when their tenure in office is threatened by resurgent opposition forces. These regimes have a track record of being able to respond to electoral setbacks not just by relying on repressive mechanisms to beat down the opposition but by taking proactive steps to address the issues that weaken their electoral position in the first place.

\footnotetext{
${ }^{1}$ Sarawak Report's editor Clare Rewcastle-Brown has claimed that "Prime Minister Najib Razak had been unable to sue over reports of his alleged involvement in misappropriation of 1Malaysia Development Berhad (1MDB) funds because he knew he would lose in any court outside Malaysia". Speaking to FMT, Rewcastle alleged that "the prime minister would never be able to sway an independent jury against news reports that implicated him in the affairs of 1MDB". For further information, see Nawar Firdaws. Najib can't sue because he will lose, claims Rewcastle. http://www.freemalaysiatoday.com/category/nation/ 2016/03/12/najib-cant-sue-because-he-will-lose-claims-rewcastle/ (March 12, 2016).

${ }^{2}$ Musa, who served as Umno's number two when Dr Mahathir was in power, said the former prime minister had similarly refused to admit to any wrongdoings and remained unfazed by the criticism that dogged his tenure. Besides that, Dr Mahathir never admitted to his mistakes, and Najib is learning from Dr Mahathir rather than me," said Musa, who has known the prime minister since Najib was a young boy. For further information, see Yahoo! News. https://sg.news.yahoo.com/najib-very-good-student-dr225926025.html (December 5, 2015).

${ }^{3}$ Shortly before Malaysia's 2013 election, $\$ 681$ million was quietly transferred into private bank accounts belonging to Prime Minister Najib Razak. These enormous transfers would later become the subject of scrutiny from Malaysian investigators as they looked at Najib's role in a controversial and debt-heavy government investment fund. Najib's statement suggests that the money was "political funding," and Apandi Ali, Malaysia's attorney general, has said that about $\$ 620$ million of the money was returned to the Saudi royal family in August 2013 because it wasn't used. Apandi suggested that there was no evidence that Najib was even aware of the transfer, and that it was given by the Saudi royal family "without any consideration." See Adam Taylor. https://www.washingtonpost.com/news/worldviews/wp/2016/01/27/themystery-behind-a-700-million-donation-from-the-saudi-royal-family-to-the-malaysian-pm/ (January 27, 2016).

${ }^{4}$ Abdullah Badawi - popularly known as Malaysia's Mr Clean - the title given to him because of his character, personal demeanour and non-involvement any big scandals. But, the title seen as a political rhetoric when he gave a business opportunity to his brother, Ibrahim Badawi, whose company, Gubahan Saujana, had been given contracts by a catering subsidiary of the national carrier, Malaysia Airlines.
} 
Through opaque privatization, then, Gubahan Saujana secured a revenue guarantee of 80 percent over a nine-year period. Besides that, analysts noted also the 'meteoric rise' of a newly listed oil and gas company, Scomi Group, in which Abdullah' son, Kamaluddin, held a majority interest. With the government having announced the formation of a new consortium to develop small oil fields, expectations mounted that Scomi would be the 'chief beneficiary' of the state contracts, driving up the firm's share price by 'an astronomical 588 percent' over its listing price four months earlier. For further information, see William Case. Abdullah Badawi's first year as Malaysia's Prime Minister. Griffith Asia Institute. www.griffith.edu.au/_data/assets/pdf_file/0020/18227/regional-outlook-volume-2.pdf. (March 14, 2016).

${ }^{5}$ There are plenty of cases that showed a negative performance in various ministries and for instance, based on the Auditor General's report (third series 2014) revealed that the two buildings, Annex 1 and 2, had been bought in 1979 and 1984 at a cost of RM1.45mil and RM1.05mil respectively. However, they have been vacant since 2002 when the Malaysian mission in the United States moved to the New Chancery building. The audit classified the buildings as wastage, seeing as the Malaysian government still had to fork out between US $\$ 2,000$ to US $\$ 3,000$ a month for utilities and maintenance. For further information, see Nandini Balakrishnan. AG report reveals how poor finance management has cost the government millions of ringgit. http://says.com/my/news/ag-report-reveals-how-poor-finance-management-has-cost-thegovernment-millions-of-ringgit. (November 24, 2015).

${ }^{6}$ The basic structural problems in this Malaysia where the rich cronies and their family members amass billions of ringgit of profit through improper means and fraudulent process is kept unchecked. That includes the monopolies, the independent power producers (IPP) and also the other related agencies. We have seen massive announcements ... but (Najib) has failed - he has no courage to address the issues ...For further information, see Anwar Ibrahim. Budget fails to address cronyism, monopolies. http://anwaribrahimblog.com/2012/09/29/budget-fails-to-address-cronyism-monopolies/ (September 29, 2012).

7 For viewing the short video clip by using drama actors to promote GST, please see https://youtu.be/6Dm5WYYPOJ4 (February 2015).

${ }^{8}$ The idea to implement a tax was not a new story in Japan when The Liberal Democratic Party government under Masayoshi Ohira had attempted to introduce a consumption tax in 1979. Ohira met a lot of opposition within his own party and gave up on his attempt after his party suffered badly in the 1979 election. Ten years later Noboru Takeshita successfully negotiated with politicians, bureaucrats, business and labor unions to introduce a consumption tax, which was introduced at a rate of $3 \%$ consumption tax in 1989. Thus, Takeshita had successfully completed the Ohira mission to introduce tax in Japan. Takeshita was forced out as prime minister because of public anger over the introduction of the new 3 percent consumption tax. For details, see Curtis, Gerald L. 1999. The logic of Japanese politics : leaders, institution and the limit of change. New York : Columbia University Press. p. 83. See also Hrebenar, Ronald J. The Japanese party system : from one-party rule to party coalition government. Boulder Co : Westview Press. p. 237.

${ }^{9}$ When Gani Patail was discontinued his service as Attorney-General, Apandi Ali has been elected to fill the vacancy. The question is who Apandi Ali and why he was appointed as Attorney-General? The answer are Apandi Ali was a UMNO man and he also a former Kelantan UMNO treasurer. Due to his involvement in UMNO prior to being appointed a judge, many people, including former opposition leader Anwar Ibrahim, have applied for Apandi not to sit in any of the panels hearing their cases. For further information, see Hafiz Yatim. Who is the new AG Apandi Ali? https://www.malaysiakini.com/news/306422. (July 28, 2015).

${ }^{10} 18$ highway concessionaires which will impose new rates for toll lanes and there are Kajang SILK, SMART, MEX expressway, Duta-Ulu Kelang (DUKE), KL-Kuala Selangor (LATAR), Baru Pantai expressway (NPE), BESRAYA, Ampang-KL (AKLEH), GUTHRIE, Kemuning-Shah Alam (LKSA), KlKarak (KLK), Damansara-Puchong (LDP), KL-Barat (SPRINT), Cheras-Kajang (GRAND SAGA) and Butterworth outer ring in Penang.

${ }^{11}$ One of the big cases that adversely affected Najib's administration was to eliminate evidence of the investigation upon him. Najib realized that deputy public prosecutor, Anthony Kevin Morais had completed the investigation on him about the corruption case and to clean his reputation as a prime minister, Kevin had to be eliminated. Kevin's brother, Charles Suresh Morais argued that Kevin was killed for other reasons and I believe these other motives were due to the fact that he knew too much about the criminal acts of those high up in the echelons of power in Malaysia and he needed to be silenced. For details, see Ida 
Lim. Kevin Morais 'knew too much' about those in power, brother claims in tussle for body. http://www.themalaymailonline.com/malaysia/article/kevin-morais-knew-too-much-about-those-in-powerbrother-claims-in-tussle-fo. November 25, 2015.

${ }^{12}$ A former Malaysian prime minister has quit the ruling United Malays National Organisation (UMNO) party over corruption concerns amid reports $\$ 1.4$ billion was deposited into Prime Minister Najib Razak's personal bank account. Mr Mahathir remains an influential figure and has become the fiercest critic of $\mathrm{Mr}$ Najib, who is facing pressure over the corruption scandal. "I won't call it UMNO anymore, this is Najib's party," Mr Mahathir said. "I feel embarrassed that I am associated with a party that is seen as supporting corruption. It had caused me to feel ashamed." See 'This is Najib's party': Former Malaysian PM Mahathir Mohamad quits party over \$1.4b 1MDB scandal. http://www.abc.net.au/news/2016-03-01/former-longserving-malaysian-pm-mahathir-mohamad-quits-umno/7211532 (March 1, 2016).

${ }^{13}$ Former premier Dr Mahathir Mohamad who has repeatedly complained about Prime Minister Najib Abdul Razak's purported motto 'cash is king' has conceded that his successor is right. In an interview with UK-based The Guardian, Mahathir alluded that several of Najib's critical opponents, including bloggers, have been bought over and have since switched sides. Previously, Mahathir had - on his blog - also complained that politicians close to Najib who have "documentary evidence" of misconduct "now gladly support him". Mahathir had also claimed that in his last meeting with the prime minister before the fallout between the two, Najib had defended his methods by declaring that "cash is king". For further information see Dr M says Najib is right, cash is king. https://www.malaysiakini.com/news/316877 (October 23, 2015).

${ }^{14}$ Private communication between James Scott and Mark Kesselman. The point is underlined by the presidential coups of Marcos in the Philippines and Park in South Korea. See Kesselman, Mark. 1973. Order or movement? The literature of political development as ideology. World Politics. 26 (1) : 139-154. p. 148.

${ }^{15} \mathrm{Mr}$ Mukhriz, who is the son of former Malaysian Prime Minister Mahathir Mohamad, resigned after weeks of calls from UMNO officials in Kedah for him to step down. Mr Mukhriz said he was resigning with immediate effect as he had lost the backing of the Kedah State Assembly. "I was informed that I have lost the majority support by the Kedah Council of Regency yesterday," he said. He explained that he did not want to prolong the leadership crisis in Kedah. "I feel a very heavy burden being been lifted off my shoulders, so we'll see what comes after this and as long as the people still want me, I will continue," he added. For further information, see Mellissa Goh. Kedah Chief Minister Mukhriz Mahathir resigns. http://www.channelnewsasia.com/news/asiapacific/kedah-chief-minister/2483134.html (February 3, 2016).

${ }^{16}$ Based on the official reason, Gani Patail was discontinued his service as Attorney-General purportedly due to kidney failure. But, the unofficial sources report that Gani had been heading a multi-agency taskforce which was investigating the claims of money being deposited in Najib's personal account. Therefore, Gani has to be replaced with another person who can clean Najib's reputation. Besides that, other government servants that had been transfer to another department to prevent leakage of $1 M D B$ secrets were former special branch Deputy Director Hamid Bador and former special Operations Director, Malaysian Anti-Corruption Commission, Bahri Mohd Zin.

$17 \mathrm{Dr} M$ : Deaf, dumb, blind UMNO forced me to work with Kit Siang. https://www.malaysiakini.com/news/335653. (March, 29, 2016).

${ }^{18}$ In politics there are no permanent friends or enemies, only permanent interests. "Permanent interests" in this case simply means - you scratch my back or groin, I scratch yours - we tame the itch and stop fidgeting. Politics is a dangerous and dirty game, and truth is not necessarily fair game. Someone can kill your mother today, but after the burial the person joins your political party and you become the best of friends. This kind of political friendship does not require any standard of proof or evidence beyond any reasonable doubt. It does not care what the rest of the family or bereaved think or feel, as long as you both stand to gain from the friendship. That is "permanent interests" for you. For further information, see Omwa Ombara. In politics, there are no permanent friends or enemies. https://thehaguetrials.co.ke/article/politicsthere-are-are-no-permanent-friends-or-enemies (February 2, 2016).

${ }^{19}$ Greene, Kenneth. 2007. Why dominants parties loss. Cambridge : Cambridge University Press. See for a more through description of what he means by dominant party authoritarian regimes. 


\section{References}

Adam Taylor. https://www.washingtonpost.com/news/worldviews/wp/2016/01/27/themystery-behind-a-700-million-donation-from-the-saudi-royal-family-to-the-malaysianpm/ (January 27, 2016).

Alagappa, M. 1995a. The anatomy of legitimacy. In M. Alagappa (edited). Political legitimacy in Southeast Asia : the quest for moral authority. Stanford : Stanford University Press.

Anuar Ibrahim. Budget fails to address cronyism, monopolies http://anwaribrahimblog.com/2012/09/29/budget-fails-to-address-cronyism-monopolies/ (September 29, 2012).

Austin, Lewis. 1975. Saints and Samurai : the political culture of the American and Japanese elites. New Haven and London : Yale University Press.

Ball, Alan R. 1988. Modern politics and government. Basingstoke, Hampshire : Macmillan Education Ltd.

Blau, P. 1964. Exchange and power in social life. New York: Wiley.

Brownlee, Jason. 2008. Bound to rule : party institutions and regime trajectories in Malaysia and the Philippines. Journal of East Asian Studies. 8 (1) : 89-118.

Candland, Christopher. 1997. Congress decline and party pluralism in India. Journal of International Affairs. 51 (1) : 19-35.

Case, William. Abdullah Badawi's first year as Malaysia's Prime Minister. Griffith Asia Institute. Www.griffith.edu.au/_data/assets/pdf_file/0020/18227/regional-outlookvolume-2.pdf. (March 14, 2016).

Crick, Bernard. 1964. In defence of politics. London : Penguin.

Crozier, M. \& Friedberg, E. 1977. L'Acteur et le systeme : les constraints de l'action collective. Paris : Editions du Seuil. p. 59.

Curtis, Gerald L. 1999. The logic of Japanese politics : leaders, institution and the limit of change. New York : Columbia University Press.

Finnemore, M. 2003. The purpose of intervention : changing beliefs about the use of force. Ithaca : Cornell University Press.

Greene, Kenneth. 2007. Why dominants parties loss. Cambridge : Cambridge University Press. 
Hafiz Yatim. Who is the new AG Apandi Ali? https://www.malaysiakini.com/news/306422. (July 28, 2015).

Hrebenar, Ronald J. The Japanese party system : from one-party rule to party coalition government. Boulder Co : Westview Press.

Huntington, Samuel P. 1971. The change to change : modernization, development and politics. Comparative Politics. 3 (3) : 283-322.

. 1991. The third wave : democratization in the late twentieth century. Norman : University of Oklahoma Press.

Ida Lim. Kevin Morais 'knew too much' about those in power, brother claims in tussle for body. http://www.themalaymailonline.com/malaysia/article/kevin-morais-knew-toomuch-about-those-in-power-brother-claims-in-tussle-fo (November 25, 2015).

Inoguchi, T. 1997. Japanese bureaucracy : coping with new challenges. In Japanese politics today : beyond karaoke democracy, eds. P. Jain and T. Inoguchi. South Melbourne : Macmillan.

Kesselman, Mark. 1973. Order or movement? The literature of political development as ideology. World Politics. 26 (1) : 139-154.

Kohli, Atul. 1994. Centralization and powerlessness : India's democracy in comparative perspective. In Joel Migdal, Atul Kohli and Vivienne Shur. (edited). State power and social forces : domination and transformation in the third world. New York : Cambridge University Press.

Machiavelli, Niccolo. 1950. The prince and the discourse. New York : Modern Library.

Magill, F.N. Sunt. 1996. International encyclopedia of government and politics. $1^{\text {st }}$ and $2^{\text {nd }}$ volume. Singapore. Toppan Co Pte Ltd.

Mahathir Mohamad : Deaf, dumb, blind UMNO forced me to work with Kit Siang. https://www.malaysiakini.com/news/335653. (March 29, 2016).

Malaysiakini. Dr M says Najib is right, cash is king. https://www.malaysiakini.com/news/316877 (October 23, 2015).

McKinsey Global Institute (MGI). 2015. Debt and (not much) deleveraging. London : MGI.

Mellissa Goh. Kedah Chief Minister Mukhriz Mahathir resigns. http://www.channelnewsasia.com/news/asiapacific/kedah-chief-minister/2483134.html (February 3, 2016). 
Migdal, J. 2001. State in society : studying how state and societies transform and constitute one another. Cambridge : Cambridge University Press.

. 2004. Mental maps and virtual checkpoint : struggles to construct and maintain state and social boundaries. In J. Migdal (edited). Boundaries and belonging : states and societies in the struggle to shape identities and local practices. Cambridge : Cambridge University Press.

Ming, Ong Kian. 2011. Malaysia in 2010 : resurgent Najib and BN, stumbling Anwar and PR. Southeast Asian Affairs. 1 (1) : 131-157.

Muhamad Takiyuddin Ismail and Ahmad Fauzi Abdul Hamid. 2014. Beyond the look east policy : United Malays National Organisation and the fall of the Liberal Democratic Party in Japan. Asian Politics \& Policy. 6 (1) : 25-44.

Mulgan, Aurelia George. 2000. Japan's political leadership deficit. Australian Journal of Political Science. 35 (2) : 183-202.

Nandini Balakrishan. AG report reveals how poor finance management has cost the government millions of ringgit. http://says.com/my/news/ag-report-reveals-how-poorfinance-management-has-cost-the-government-millions-of-ringgit (November 24, 2015).

Nawar Firdaws. http://www.freemalaysiatoday.com/category/ nation/2016/03/12/najibcant-sue-because-he-will-lose-claims-rewcastle/ (March 12, 2016).

Omwa Ombara. In politics, there are no permanent friends or enemies. https://thehaguetrials.co.ke/article/politics-there-are-are-no-permanent-friends-or-enemies (February 2, 2016).

O'Shannassy, Michael. 2013. More talk than walk? UMNO, "new politics" and legitimation in contemporary Malaysia. Journal of Contemporary Asia. 43 (3) : 428-451.

Panebianco, Angelo. 1988. Political parties : organizational and power. Translated by Marc Silver. Cambridge : Cambridge University Press.

Saiyid Radzuwan Syed Sopi. 2014. The fall and rise of LDP : a study on Japan coalition politics (1993-2006). Ph.D. thesis. UKM : Bangi

Stockwin J.A.A. 2006. To oppose or to appease? Parties out of power and the need for real politics in Japan. Japan Forum. 18 (1) : 115-132.

Suryadinata, Leo. 1997a. Democratization and political succession in Soeharto's Indonesia. Asian Survey. 37 (3) : 269-280.

The Economist. Not yet out of Mahathir's shadow. January 31, 2004 : 25. 
Walzer, M. 1967. On the road of symbolism in political thought. Political Science Quarterly. 82 (2) : 191-204.

Yahoo Mail. https://sg.news.yahoo.com/najib-very-good-student-dr-225926025.html (December 5, 2015).

Yeoh, See Onn. 2009. Najib's first 100 days : no honeymoon. Petaling Jaya : Gerakbudaya.

\section{MALAYSIAN DEMOCRATIC DILEMMAS IN THE ERA OF NAJIB RAZAK}

Saiyid Radzuwan Syed Sopi (corresponding author)

School of Distance Education

Universiti Sains Malaysia (USM)

11800 Penang

Malaysia

pbsaiyid@usm.my

+6-04-6535946 (office) / +6-014-241-1754 (mobile)

Ahmad Fauzi Abdul Hamid

School of Distance Education

Universiti Sains Malaysia (USM)

11800 Penang

Malaysia

afauzi@usm.my

+6-04-6532278 (office) / +6-016-475-7392 (mobile) 